\title{
Comparison of patient comfort after coronary angiography by standard arterial access approaches
}

\author{
Joanna K. Rutka, Krzysztof Bryniarski, Tomasz Tokarek, Grzegorz Dębski, Agata Krawczyk, \\ Anna Żabówka, Zbigniew Siudak, Dariusz Dudek
}

Second Department of Cardiology and Cardiovascular Interventions, Jagiellonian University, Medical College, University Hospital, Krakow, Poland

\begin{abstract}
Background: Radial access during coronary angiography has become an increasingly popular alternative to femoral access. The procedural outcomes and complications of these two approaches have been thoroughly evaluated; however, no studies have focused exclusively on the postprocedural quality of life of patients.

Aim: To determine and compare both methods from the patient's point of view.

Methods: Data were gathered from 165 consecutive patients scheduled for elective coronary angiography (from October 2011 to June 2012). The choice of the access site was left at operator's discretion. Femoral and radial groups consisted of 91 and 74 patients, respectively. Quality of life was assessed by the Short Form of the McGill Questionnaire and a self-designed questionnaire (Questionnaire II) consisting of eight questions evaluating the procedure-specific aspects of recovery time. After three months from index hospitalisation post-discharge interviews were conducted using a modified version of Questionnaire II with an additional two questions.

Results: Patients from the transfemoral approach group characterised their pain (according to McGill Questionnaire) more often as aching (mean value \pm SD: $0.84 \pm 1.2$ vs. $0.21 \pm 0.6 ; p=0.003)$, heavy $(0.29$ vs. $0.027 ; p=0.02$ ), and exhausting $(0.22 \pm 0.7$ vs. $0.07 \pm 0.2 ; p=0.037)$. Moreover, in Questionnaire II they indicated tenderness of the puncture site $(0.42 \pm 0.8$ vs. $0.23 \pm 0.07 ; p=0.00004)$ more frequently.

Conclusions: The quality of life of patients who underwent coronary angiography from radial access was remarkably better in terms of pain characteristic and overall discomfort.
\end{abstract}

Key words: quality of life, radial access, coronary angiography

Kardiol Pol 2016; 74, 1: 68-74

\section{INTRODUCTION}

Femoral artery access (TFA) has been considered for many years to be a standard approach for invasive coronary procedures. However, transradial access (TRA) has become an essential alternative for both elective and acute coronary angiography, offering a substantial decrease in access site complications (mainly local bleedings) [1,2] and shorter time to ambulation. These may lead to reduced costs of hospital stay $[3,4]$. Data on reduced mortality among ST segment elevation myocardial infarction (STEMI) patients when treated via radial approach have already been reported [2]. Furthermore, current European Society of Cardiology (ESC)
STEMI guidelines recommend transradial approach as class Ila provided that it is performed by an experienced operator [5].

According to the World Health Organisation definition, quality of life (QoL) is an individual's perception of widely understood well-being [6]. Thus, it is recognised as an important factor that should be taken into consideration when comparing and choosing different treatment and diagnostic strategies, especially in cases of equal efficacy and safety. Importantly, tools specially designed for that purpose allow the evaluation of patient-cantered consequences due to potential differences in therapeutic approaches.

\footnotetext{
Address for correspondence:

Joanna K. Rutka, MD, Second Department of Cardiology and Cardiovascular Interventions, Jagiellonian University, Medical College, University Hospital,

ul. Mikołaja Kopernika 17, 31-501 Kraków, Poland, e-mail: asia.rutka@gmail.com

Received: 13.09.2014 Accepted: 07.04.2015 Available as AoP: 18.06.2015

Kardiologia Polska Copyright (c) Polskie Towarzystwo Kardiologiczne 2016
} 
Previous trials have proven the efficacy and feasibility of transradial catheterisation although the impact on the QoL of the early convalescence period has not been widely evaluated $[2,3]$.

The role of access site choice in post-procedural convalescence is commonly neglected, while it is essential from the patients' perspective. The primary aim of the current study was to compare patient comfort and QoL after transradial and traditional transfemoral approach during elective coronary angiography procedures.

\section{METHODS}

A series of consecutive patients who underwent elective diagnostic coronary catheterisation for stable coronary artery disease were included in the registry study. Data were gathered in the Second Department of Cardiology, Jagiellonian University Medical College, Krakow, Poland from October 2011 to June 2012.

Qualification for the procedure was in accordance with current guidelines [7]. All diagnostic coronary angiographies were performed from radial or femoral access, according to the operator's discretion. Patients with an ad hoc percutaneous coronary intervention ( $\mathrm{PCl}$ ) following the angiography were excluded from this analysis. There were no other exclusion criteria, and all patients not undergoing ad hoc $\mathrm{PCl}$ were included into the study. None of the patients enrolled to the study received a closure device, due to the standard manual compression protocols used in our centre. Pain medications were administered according to the standard regimen based on current ESC guidelines.

Clinical data were prospectively gathered after the procedure during index hospitalisation.

The level of discomfort following the procedure was assessed by the Short Form of the McGill Questionnaire (Questionnaire I) [8] and a self-designed eight-item questionnaire evaluating various aspects of recovery time (Questionnaire II) (Table 1). The McGill Questionnaire is a well-established tool for assessing the quality and intensity of pain. It consists of 15 descriptors of pain (11 sensory; four affective), present pain intensity index, and visual analogue scale (VAS). The questionnaire has been shown to be a reliable instrument for measurement of pain in the clinical setting, validated for different patient populations. In the self-designed questionnaire a series of eight procedure-specific questions were used. Patients were requested to rate their discomfort with a numerical scale from 0 to 5 related to particular parts of the convalescence period. 0 was explained to the patients as a lack of discomfort and 5 was explained to the patients as the strongest discomfort they could ever imagine. Five of the included questions were access-related: compression after vascular sheath removal (which relates to amount of discomfort caused by compression), numbness and pain of the punctured limb, feeling of foreign body (vascular sheath) presence, troublesome bleeding, or nuisance due to a puncture site haematoma. The remaining two: necessity of long immobilisation and backache, were related to decreased mobility. In the case of bladder catheterisation for the purpose of the procedure patients were given the possibility to assess this additional aspect.

Three months after the procedure, follow-up consisting of re-evaluation of in-hospital QoL was performed. To ensure the most thorough follow-up, post-discharge interviews were conducted by telephone in all patients enrolled in the study. We used a modified version of Questionnaire II (IIA) with two additional questions appended, targeted at general perception of convalescence from the time perspective ("How would you describe your overall discomfort during the hospital stay?" and "Would you, considering your experience, agree to undergo coronary angiography again, if necessary?").

Informed consent for baseline and follow-up interviews was obtained from all patients enrolled to the study.

\section{Statistical analysis}

Data were analysed according to the established statistical protocols. The results are presented as percentages of patients or means \pm standard deviation (SD) when applicable. Differences between groups were tested using $\chi^{2}$ test for categorical variables and Mann-Whitney test for continuous ones. All tests were two tailed and a $p$ value of $<0.05$ was considered to be

Table 1. Self-designed questionnaire

\begin{tabular}{|c|c|c|c|c|c|c|}
\hline Could you please rate your discomfort after angiography caused by: & 0 & 1 & 2 & 3 & 4 & 5 \\
\hline \multicolumn{7}{|l|}{ 1. Compression after vascular sheath removal } \\
\hline \multicolumn{7}{|l|}{ 2. Numbness of the punctured limb } \\
\hline \multicolumn{7}{|l|}{ 3. Foreign body presence } \\
\hline \multicolumn{7}{|l|}{ 4. Necessity of long immobilisation } \\
\hline \multicolumn{7}{|l|}{ 5. Punctured limb pain } \\
\hline \multicolumn{7}{|l|}{ 6. Backache after the procedure } \\
\hline \multicolumn{7}{|l|}{ 7. Bleeding/puncture site haematoma } \\
\hline 8. Bladder catheterisation (if applicable) & & & & & & \\
\hline
\end{tabular}


statistically significant. All statistical analyses were performed using Statistica 10.0 software [Statsoft, Tulsa, Oklahoma, USA].

\section{RESULTS}

The study population consisted of 165 patients. There were 74 (45\%) patients assigned to the TRA group and 91 (55\%) to the TFA group. There were $51(68.9 \%)$ men in the TRA and $54(59.4 \%)$ in the TFA group, respectively $(p=0.191)$. The mean age in these groups was $63.3 \pm 8.4$ vs. $64.7 \pm 11$, respectively, and they did not differ significantly $(p=0.361)$. Patient baseline demographics, past medical history, and clinical status were similar in both groups.

No significant differences were observed regarding the time of data collection in both groups. Information from questionnaires during hospital stay was obtained on average $1.49 \pm 0.69$ days after the angiography in the TFA group vs. $1.39 \pm 0.68$ days in the TRA group $(p=0.310$ ). There were no differences in overall discomfort between the groups at the time of hospital interviews $(0.41 \pm 0.88$ in TFA vs. $0.43 \pm 0.81$ in TRA group in a six-point scale; $p=0.689$ ).

Using 15 pain characteristics provided by Questionnaire I, patients from the TFA group characterised their pain more often as aching (mean value \pm SD: $0.84 \pm 1.2$ vs. $0.21 \pm 0.6$; $\mathrm{p}=0.003)$, heavy $(0.29 \pm 0.7$ vs. $0.03 \pm 0.2 ; \mathrm{p}=0.02)$, and exhausting $(0.22 \pm 0.7$ vs. $0.07 \pm 0.2 ; p=0.037)$. Moreover, they indicated tenderness of the puncture site $(0.42 \pm 08$ vs. $0.23 \pm 0.07 ; p<0.0001)$ more frequently. None of the parameters favoured the TFA group.

The scoring of overall pain intensity marked on a visual scale (maximal value $100 \mathrm{~mm}$ ) was statistically higher in the TFA group $(34.8 \pm 20.1 \mathrm{~mm}$ vs. $24.6 \pm 18.3 \mathrm{~mm} ; \mathrm{p}<0.001)$ (Fig. 1).

At the time of obtaining the QoL scores the majority of the measures favoured the TRA group. Discomfort associated with immobilisation was observed less frequently in the TRA group. In comparison to TFA, inconvenient groin compression dressing and long bed rest was not required to achieve haemostasis after the procedure, which eliminated back pain. However, numbing of the punctured limb was indicated as more bothersome in the TRA group (Fig. 2).

Initially, there was no difference in reported discomfort level at the puncture site as well as pain level due to manual compression after vascular sheath removal.

In the three months follow-up (conducted on all patients, with $87.2 \%$ response rate) differences in positive response rate for immobilisation (mean values \pm SD: $2.6 \pm 1.5$ vs. $1.45 \pm 0.9$ for TFA and TRA group, respectively) and backache $(2.2 \pm 1.6$ vs. $0.79 \pm 1 ; p<0.0001)$ remained significant. A statistically higher level of pain during compression was reported $(0.8 \pm 1.1$ vs. $0.71 \pm 0.9)$. However, the difference in punctured limb numbness, which primarily favoured the femoral cohort, equalised to a non-significant level in follow-up interviews. Interestingly, patients from both

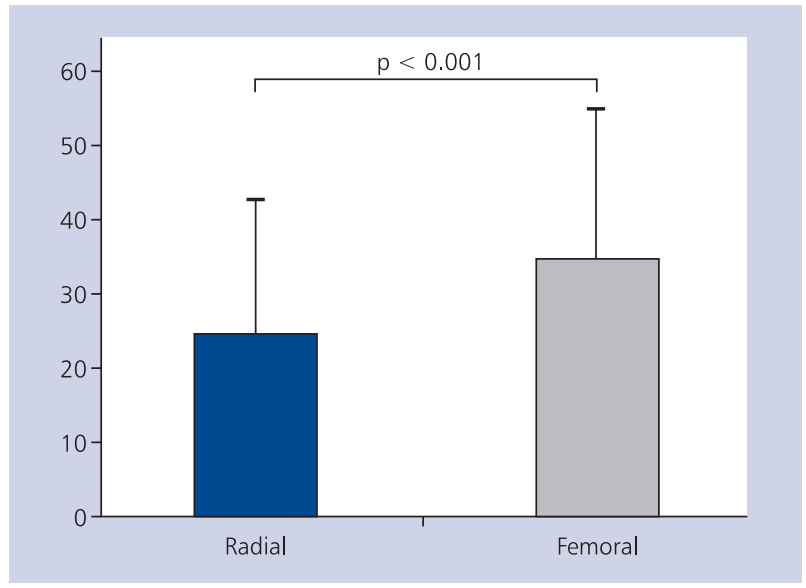

Figure 1. The scoring of overall pain intensity in the femoral artery access and transradial access groups (Questionnaire I)

groups generally tended to describe discomfort as lower in most scores, with the exception of inconvenience due to bladder catheterisation (Fig. 2). Detailed distribution of the scores from Questionnaire II and IIA are presented in Tables 2 and 3.

Regarding the additional questions in the follow-up interview, overall discomfort was more often described as lower in the TRA group (Fig. 3).

The percentage of positive answers of patients who would agree on diagnostic coronary angiography again, if necessary, was high and comparable between groups (96.9\% vs. 92.7\%; $\mathrm{p}=0.26)$.

\section{DISCUSSION}

In the current study it has been proven that TRA is significantly superior for patients in comparison to TFA when regarding QoL. The first transradial angiography was described in 1989 [9]. Since then the advantages of TRA over TFA have been extensively reviewed in the literature; however, just a few have evaluated QoL in early convalescence when comparing both approaches [2, 3].

The femoral route is widely used for diagnostic procedures as well as coronary interventions; nevertheless, the debate on optimal access choice is ongoing.

TRA has been shown to be technically more challenging, requiring a longer learning curve for the operator, and therefore it has gained acceptance slowly. Studies have previously indicated that longer procedure duration, and high use of contrast media and radiation exposure were associated with TRA [2, 10-14]. However, those are experience-dependent and once the operator has achieved proficiency, little difference is noted in the rates of successful radial procedures. Accordingly, Ball et al. [15] observed a consistent reduction in complication rate with higher use of the transradial route. In the CARAFE study Louvard et al. [1] showed comparable success rates as with the use of femoral access with reduced rate of vascular complications. 


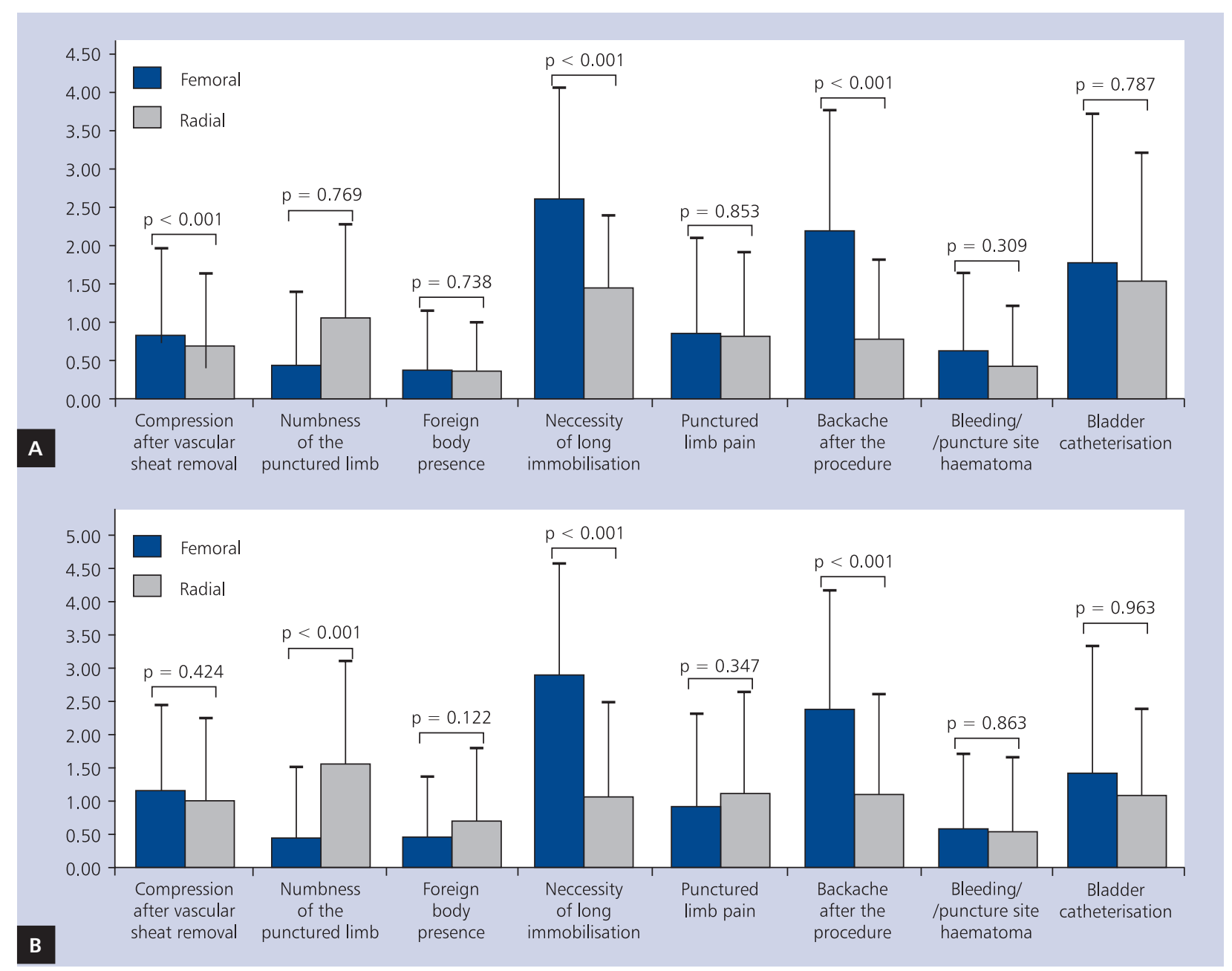

Figure 2. Results from Questionnaire II — baseline (A) and follow-up interview (B)

Table 2. Detailed results from Questionnaire II during hospital stay (\% of positive answers in femoral artery access and transradial access groups, respectively)

\begin{tabular}{|lccccc|}
\hline Score & $\mathbf{1}$ & $\mathbf{2}$ & $\mathbf{3}$ & $\mathbf{4}$ & $\mathbf{5}$ \\
\hline Compression after vascular sheath removal & 23.1 & 20.9 & 11 & 0 & 3.3 \\
& 27 & 13.5 & 5.4 & 4.1 & 2.7 \\
Numbness of the punctured limb & 11 & 3.3 & 4.4 & 2.2 & 1.1 \\
Foreign body presence & 25.7 & 12.2 & 14.9 & 6.8 & 6.8 \\
Necessity of long immobilisation & 15.4 & 7.7 & 3.3 & 0 & 1.1 \\
& 20.3 & 10.8 & 5.4 & 2.7 & 0 \\
Punctured limb pain & 8.8 & 14.3 & 19.8 & 22 & 20.9 \\
Backache after the procedure & 18.9 & 13.5 & 10.8 & 4.1 & 2.7 \\
& 16.5 & 7.7 & 7.7 & 3.3 & 4.4 \\
Bleeding/puncture site haematoma & 10.8 & 14.9 & 8.1 & 6.8 & 4.1 \\
(subjective patient's evaluation) & 8.8 & 11 & 19.8 & 22 & 12.1 \\
Bladder catheterisation (if applicable) & 13.5 & 16.2 & 6.8 & 4.1 & 5.4 \\
& 6.6 & 7.7 & 4.4 & 4.4 & 1.1 \\
\hline
\end{tabular}


Table 3. Detailed results from Questionnaire IIA in the follow-up (\% of positive answers in femoral artery access and transradial access groups, respectively)

\begin{tabular}{|lccccc}
\hline Score & $\mathbf{1}$ & $\mathbf{2}$ & $\mathbf{3}$ & $\mathbf{4}$ & $\mathbf{5}$ \\
\hline Compression after vascular sheath removal & 22.5 & 16.3 & 5 & 0 & 2.5 \\
Numbness of the punctured limb & 27 & 12.7 & 6.3 & 0 & 0 \\
& 17.5 & 6.3 & 0 & 2.5 & 1.3 \\
Foreign body presence & 17.5 & 17.5 & 14.3 & 3.2 & 0 \\
& 11.3 & 7.5 & 3.8 & 0 & 0 \\
Necessity of long immobilisation & 17.5 & 9.5 & 0 & 0 & 0 \\
& 11.3 & 25 & 27.5 & 13.8 & 12.5 \\
Punctured limb pain & 25.4 & 9.5 & 4.8 & 1.6 & 0 \\
Backache after the procedure & 21.3 & 10 & 6.3 & 5 & 1.3 \\
Bleeding/ puncture site haematoma & 21.9 & 14.1 & 9.5 & 1.6 & 0 \\
(subjective patient's evaluation) & 15 & 5 & 22.5 & 16.3 & 12.5 \\
Bladder catheterisation (if applicable) & 25.4 & 11.1 & 3.2 & 1.6 & 3.2 \\
& 13.8 & 10 & 10 & 0 & 0 \\
& 15.6 & 9.3 & 3.2 & 1.2 & 0 \\
\hline
\end{tabular}

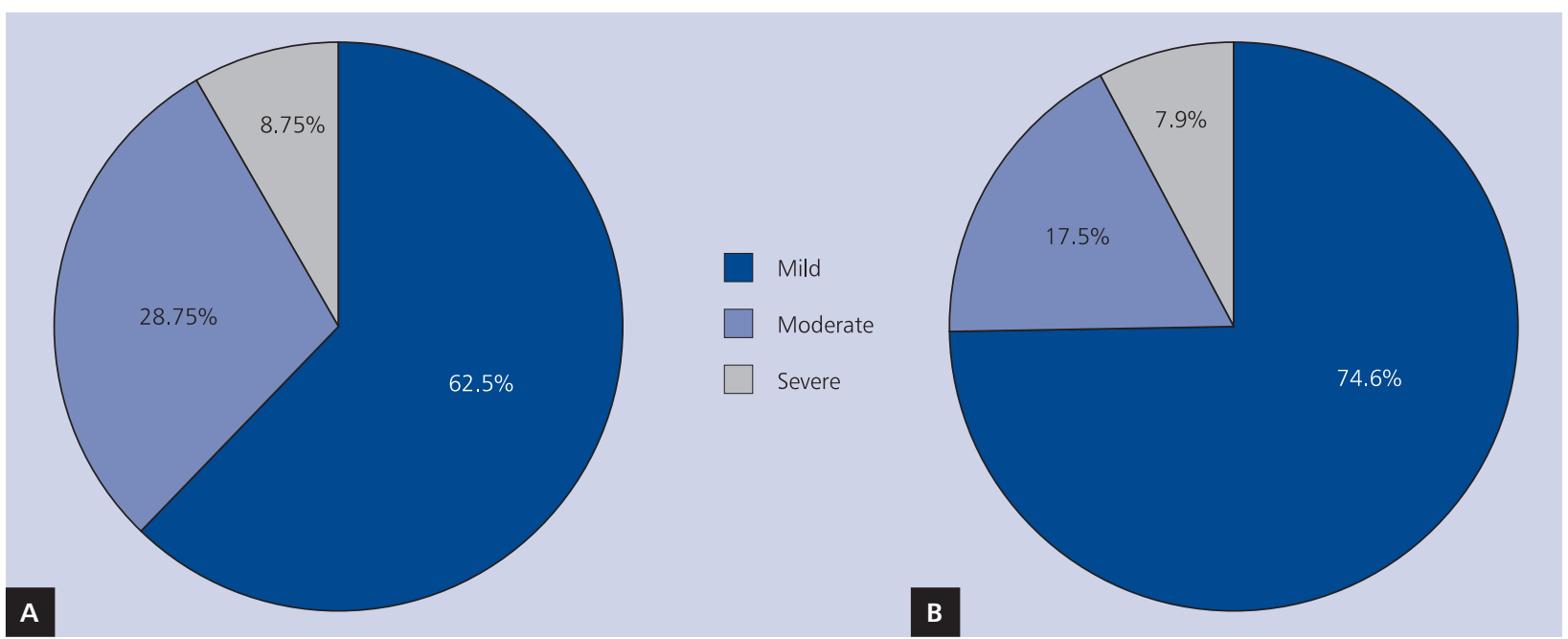

Figure 3. Overall discomfort related to the convalescence after the procedure (Questionnaire IIA); $\mathbf{A}$. Femoral artery access group; B. Transradial access group

Finally, transradial catheterisation was associated with significant cost reduction, mainly as a result of shorter hospital stay when performing TRA [3, 16, 17].

Thr recently published RIVAL trial $[18,19]$ showed that there was a significant reduction in major vascular complications in the radial group (1.4\% radial vs. $3.7 \%$ femoral; $\mathrm{p}<0.001$ ) while maintaining a similar procedure success rate.

Considering the increasing use of invasive diagnostic procedures, it should be emphasised that hospitalisation and procedure-related discomfort affects not only the physical element but also all aspects of well-being, including impairment of daily activities and poor functional status. Undeniably, vascular access for cardiac catheterisation influences significantly subsequent patient care and post procedural QoL. Thus, it is essential to introduce a holistic approach in the clinical decision-making process.

The present study evaluated both procedures from the patients' perspective in a standard population undergoing elective diagnostic cardiac catheterisation, and indicated superiority of the radial approach in comparison to the femoral 
approach. Our outcomes are mostly consistent with other studies comparing both access sites in terms of QoL.

Patients' strong preference for transradial procedures has been previously observed. Cooper et al. [3] measured health-related QoL in 200 patients referred for cardiac catheterisation, and reported increased occurrence of backache and access site pain as well as bathroom difficulty in the TFA group. Those difficulties may be exaggerated in specific groups of patients, such as the elderly, obese, or those suffering from chronic arthritis. However, in our study the patients indicated comparable pain at the access site in both groups. This may be related to the difference in data collection time (one week after the procedure, whereas in our study it was $1.44 \pm 0.68$ days on average). Moreover, Copper et al. [3] also demonstrated that TRA was associated with markedly shorter hospital stay and faster mobilisation, which improved indexes of QoL in that group. In another recent study Koltowski et al. [20] proved that radial access is associated with fewer problems with mobility and self-care, which is consistent with our study.

In contrast, in the study from Reddy et al. [21] time to ambulation rather than access site defined the differences in QoL. Hence, the use of vascular closure devices or $4 \mathrm{~F}$ sheath size for the femoral approach gives results similar to the transradial approach [21]. On the other hand, closure devices contribute significantly to the total procedure cost, and data on the following vascular complication are conflicting [22, 23].

In our study we found the difference in the rates of early-onset puncture site complications insignificant. However, no objective medical assessment of the occurrence of bleeding complications was performed for the purpose of the current study because the main objective was to evaluate post-procedural comfort only from the patients' perspective. Hence, puncture site haematoma and bleeding were regarded as a positive answer only if patients indicated a measurable effect on post-procedural discomfort.

\section{Limitations of the study}

Our findings should be interpreted in the context of potential limitations. The main limitation of the current study is the relatively small sample size and lack of randomisation. Furthermore, patients receiving vascular closure devices designed for femoral approach, which may promote faster ambulation compared to the tie of ambulation without using closure devices, have not been included in the analysis. In addition, selection of vascular sheath as well as catheter size might have affected subjective discomfort rating. Our questionnaire has been developed exclusively for the purpose of the current study, so it has not been validated in different patient populations. Furthermore, the Polish version of the McGill Questionnaire that we used to evaluate pain intensity and characteristics was not validated for the indicated population.

\section{CONCLUSIONS}

Our results indicate that the transradial technique for elective coronary angiography is a viable alternative to the traditional transfemoral approach in improving patient comfort during hospital recovery. The quality of life of patients who underwent coronary angiography from radial accesses was remarkably better in terms of pain characteristics and overall discomfort.

\section{Conflict of interest: none declared}

\section{References}

1. Louvard Y, Lefèvre T, Allain A, Morice M. Coronary angiography through the radial or the femoral approach: the CARAFE study. Catheter Cardiovasc Interv, 2001; 52: 181-187.

2. Pristipino C, Trani C, Nazarro MS et al. Major improvement of percutaneous cardiovascular procedure outcomes with radial artery catheterisation: results from the PREVAIL study. Heart, 2009; 95: 476-482. doi: 10.1136/hrt.2008.150714.

3. Cooper CJ, El-Shiekh RA, Cohen DJ et al. Effect of transradial access on quality of life and cost, of cardiac catheterization: A randomized comparison. Am Heart J. 1999; 138 (3 Part 1): 430-436.

4. Jeffrey M. Schussler. Effectiveness and safety of transradial artery access for cardiac catheterization. Proc (Bayl Univ Med Cent), 2011; 24: 205-209.

5. ESC Guidelines for the management of acute myocardial infarction in patients presenting with ST-segment elevation. Eur Heart J, 2012; 33: 2569-2619

6. WHOQOL Group. The World Health Organization Quality of Life Assessment (WHOQOL): position paper from the World Health Organization. Social Science Med, 1995; 41: 1403-1149.

7. 2013 ESC Guidelines on the management of stable angina pectoris. Eur Heart J, 2013; 34: 2949-3003. doi: 10.1093/eurheartj/eht296.

8. Melzack R. The short-form McGill Pain Questionnaire. Pain,1987; 30: 191-197.

9. Campeau L, Percutaneous radial artery approach for coronary angiography. Catheter Cardiovasc Diagn, 1989; 16: 3-7.

10. Jolly SS, Amlano S, Hamon M et al. Radial versus femoral access for coronary angiography or intervention and the impact on major bleeding and ischemic events: A systematic review and meta-analysis of randomized trials. Am Heart J, 2009; 157: 132-140.

11. Sunil V. Rao, Ivo Bernat, Olivier F. Bertrand. Remaining challenges and opportunities for improvement in percutaneous transradial coronary procedures. Eur Heart J, 2012; 33: 2521-2528.

12. Carillo X, Mauri J, Fernandez-Nofrerias E et al. Safety and efficacy of transradial access in coronary angiography: 8-year experience. J Invasive Cardiol, 2012; 24: 346-351.

13. Guédès A, Dangoisse V, Gabriel L et al. Low rate of conversion to transfemoral approach when attempting both radial arteries for coronary angiography and percutaneous coronary intervention: a study of 1,826 consecutive procedures. J Invasive Cardiol, 2010; 22: 391-397.

14. Brueck M, Bandorski D, Kramer W, et al. A randomized comparison of transradial versus transfemoral approach for coronary angiography and angioplasty. J Am Coll Cardiol Cardiovasc Interv, 2009; 2: 1047-1054. doi: 10.1016/j.jcin.2009.07.016.

15. Ball WT, Sharieff W, Jolly SS et al. Characterization of operator learning curve for transradial coronary interventions. Circ Cardiovasc Interv, 2011; 4: 336-341. doi: 10.1161/CIRCINTERVENTIONS.110.960864.

16. Kiemeneij F, Hofland J, Laarman GJ et al. Cost comparison between two modes of Palmaz Schatz coronary stent implantation: transradial bare stent technique vs. transfemoral sheath-protected stent technique. Cathet Cardiovasc Diagn, 1995; 35: 301-308.

17. Agostoni P, BIondi-Zoccai G, De Benedictis L. Radial versus femoral approach for percutaneus coronary diagnostic and interventional procedures, J Am Coll Cardiol, 2004; 44: 2.

18. Hale S, Mann T. Examining the appropriateness of radial or femoral access. Interv. Cardiol, 2012; 4: 675-687.

19. Jolly SS, Yusuf S, Cairns J et al. Radial versus femoral access for coronary angiography and intervention in patients with acute coronary syndromes (RIVAL): a randomised, parallel group, multicentre trial. Lancet, 2011; 377: 1409-1420. 
20. Koltowski L, Koltowska-Haggstrom M, Filipiak KJ et al. Quality of life in patients with ST-segment elevation myocardial infarction undergoing percutaneous coronary intervention--radial versus femoral access (from the OCEAN RACE Trial). Am J Cardiol, 2014; 114: $516-521$.

21. Reddy BK, Brewster PS, Walsh T et al. Randomized comparison of rapid ambulation using radial, 4 French femoral access, or femoral access with AngioSeal closure. Catheter Cardiovasc Interv, 2004; 62: 143-149.

22. Koreny M, Riedmüller E, Nikfardjam Met al. Arterial puncture closing devices compared with standard manual compression after cardiac catheterization: systematic review and meta-analysis. JAMA, 2004; 291: 350-357.

23. Dauerman HL, Applegate RJ, Cohen DJ. Vascular closure devices: the second decade. J Am Coll Cardiol, 2007; 50: 1617-1626.

Cite this article as: Rutka JK, Bryniarski K, Tokarek T et al. Comparison of patient comfort after coronary angiography by standard arterial access approaches. Kardiol Pol, 2016; 74: 68-74. doi: 10.5603/KP.a2015.0118.

\title{
Porównanie jakości życia pacjentów po zabiegu planowej koronarografii $\mathrm{z}$ dostępu promieniowego i udowego
}

\author{
Joanna K. Rutka, Krzysztof Bryniarski, Tomasz Tokarek, Grzegorz Dębski, Agata Krawczyk, \\ Anna Żabówka, Zbigniew Siudak, Dariusz Dudek
}

II Oddział Kliniczny Kardiologii oraz Interwencji Sercowo-Naczyniowych, Collegium Medicum Uniwersytetu Jagiellońskiego, Kraków

\section{Streszczenie}

Wstęp: Użycie dostępu promieniowego przy planowych zabiegach koronarograficznych stało się interesującą alternatywą dla klasycznego dostępu przez tętnicę udową. Porównanie obu dostępów pod kątem efektywności i bezpieczeństwa jest szeroko opisywane w literaturze. Jednak żadne z dotychczasowych badań nie skupiało się wyłącznie na jakości życia pacjentów w czasie rekonwalescencji szpitalnej.

Cel: Celem pracy były ocena i porównanie jakości życia po zabiegu planowej koronarografii z dostępu promieniowego i udowego z perspektywy pacjenta.

Metody: Do badania włączono 165 kolejnych pacjentów. Grupy dostępu promieniowego i udowego liczyły odpowiednio 74 i 91 osób. Jakość życia oceniono za pomocą skróconej wersji kwestionariusza McGill oraz kwestionariusza dedykowanego (Kwestionariusz II) zaprojektowanego na potrzeby tego badania, oceniającego 8 specyficznych aspektów dyskomfortu pozabiegowego. Po 3 miesiącach od hospitalizacji ponownie oceniono jakość życia w czasie rekonwalescencji szpitalnej, używając zmodyfikowanej wersji Kwestionariusza II (IIA), zawierającej 2 dodatkowe pytania dotyczące ogólnej oceny komfortu pozabiegowego z punktu widzenia pacjentów.

Wyniki: Chorzy z grupy dostępu udowego częściej określali ból jako: uciążliwy (śr. \pm SD: 0,84 $\pm 1,2$ vs. 0,21 $\pm 0,6 p=0,003$ ), ciężki $(0,29$ vs. 0,$027 ; p=0,02)$ i wyczerpujący $(0,22 \pm 0,7$ vs. 0,07 $\pm 0,2 ; p=0,037)$. Ponadto częściej wskazywali na ból w miejscu dostępu jako dokuczliwy $(0,42 \pm 0,8$ vs. 0,23 $\pm 0,07 ; p=0,00004)$.

Wnioski: Wykorzystanie dostępu promieniowego przy planowych zabiegach poprawia jakość życia i zwiększa komfort pacjentów w okresie rekonwalescencji szpitalnej.

Słowa kluczowe: jakość życia, dostęp promieniowy, dostęp udowy 